\title{
Notes on the vocalizations of Hill Prinia (Prinia atrogularis)
}

\section{Peter Boesman}

In the following we briefly analyze and compare voice of the different races of Hill Prinia (Prinia atrogularis). We also try to quantify the extent of any vocal differences using the criteria proposed by Tobias et al. (2010), as a support for taxonomic review. We have made use of sound recordings available on-line from Xeno Canto (XC).

Song in all races is a fairly complex note repeated at a steady pace. Comparison of song of the different races:
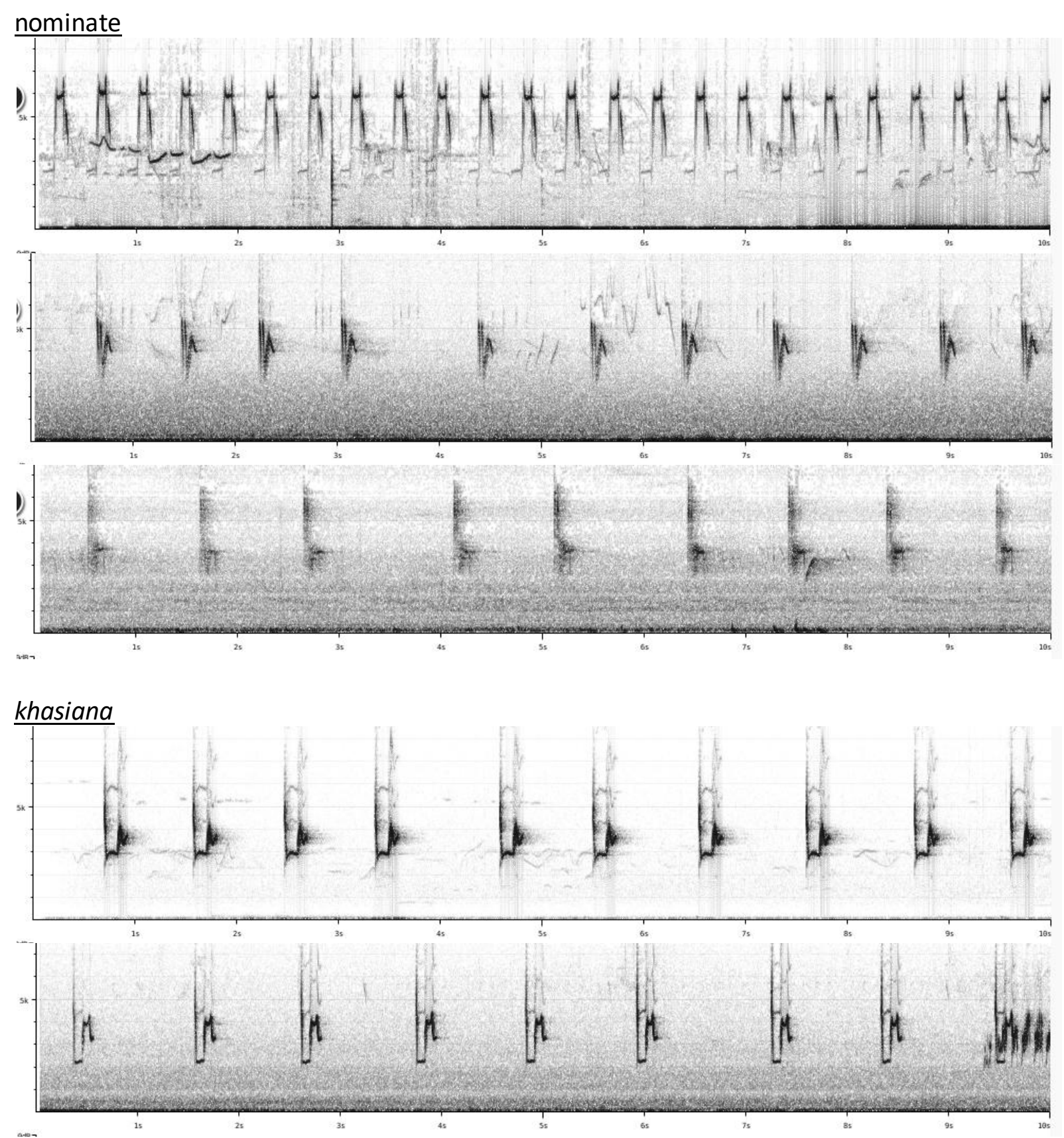


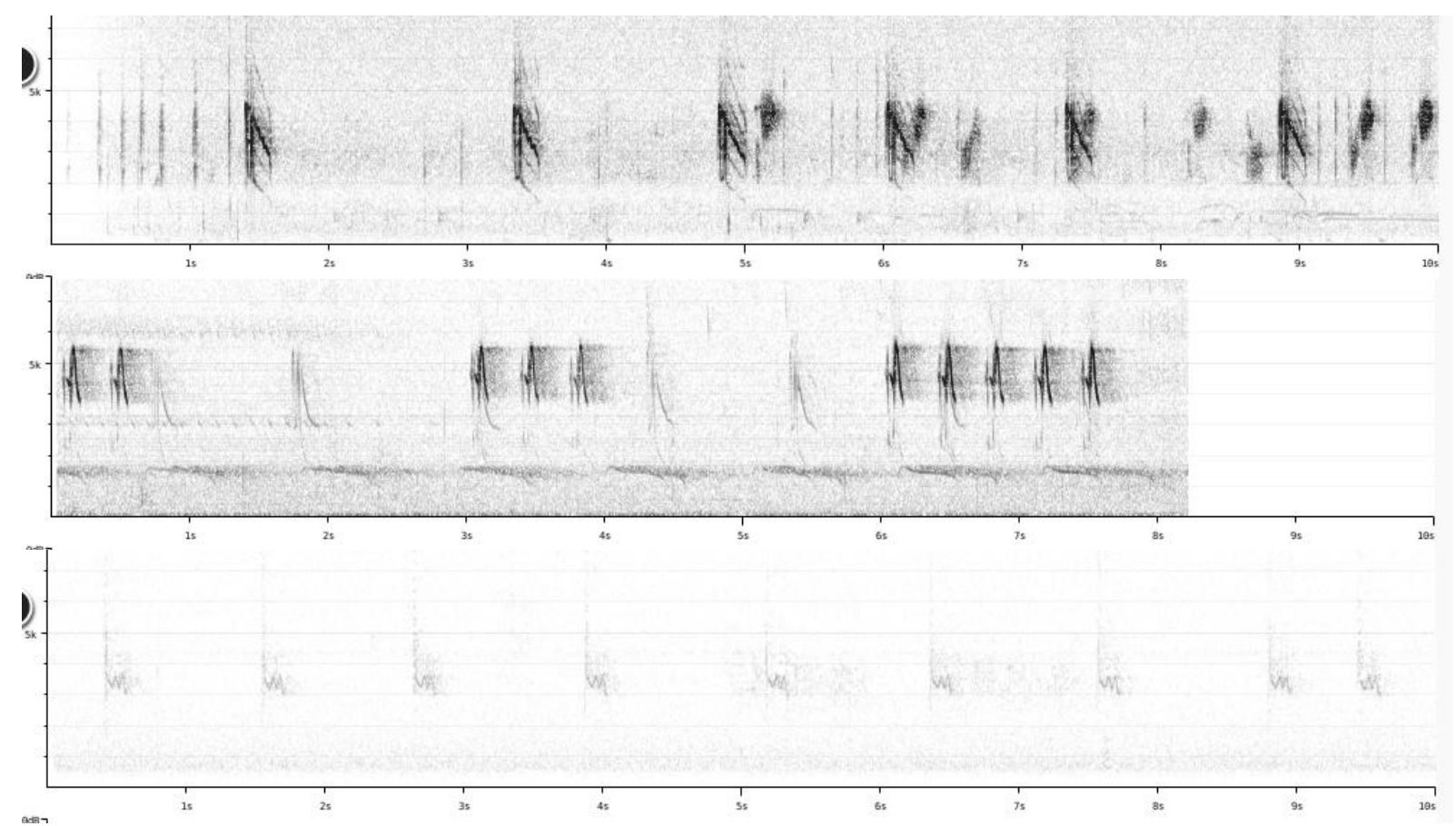

Selected recordings from other races:

1) compare with example 1 and 2 of khasiana:

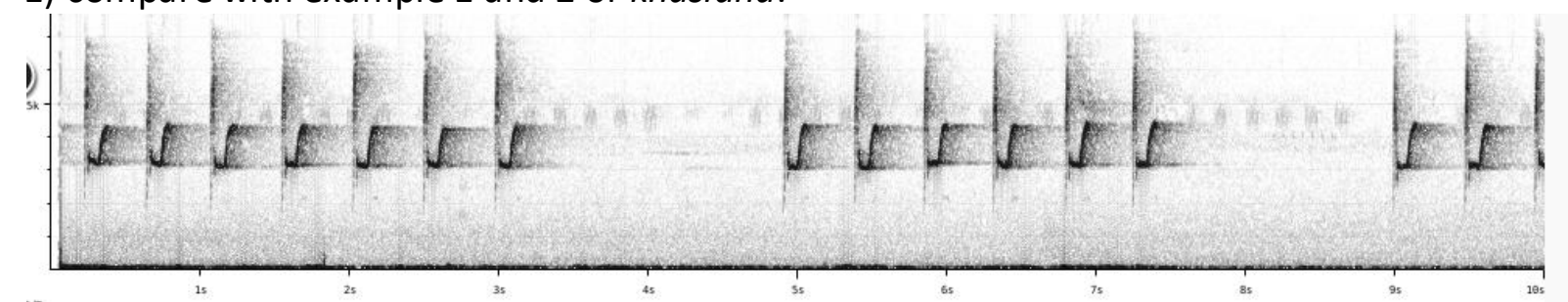

2) compare with example 4 of khasiana:

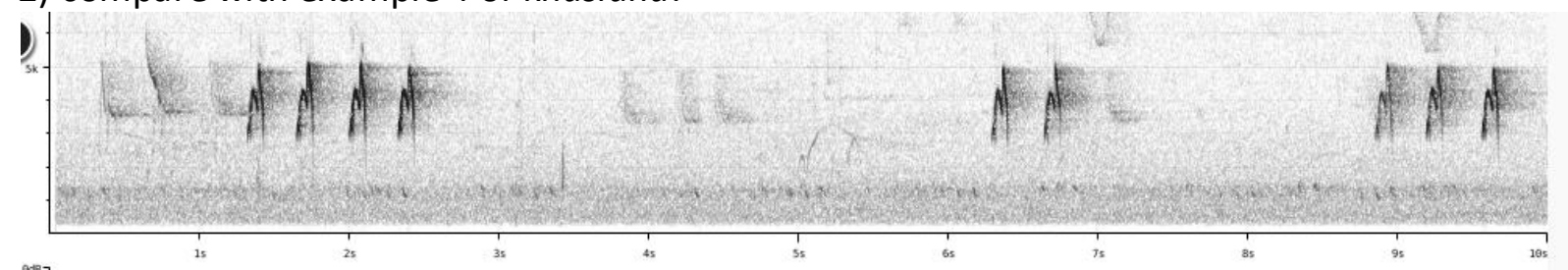

3) compare with example 2 of nominate:

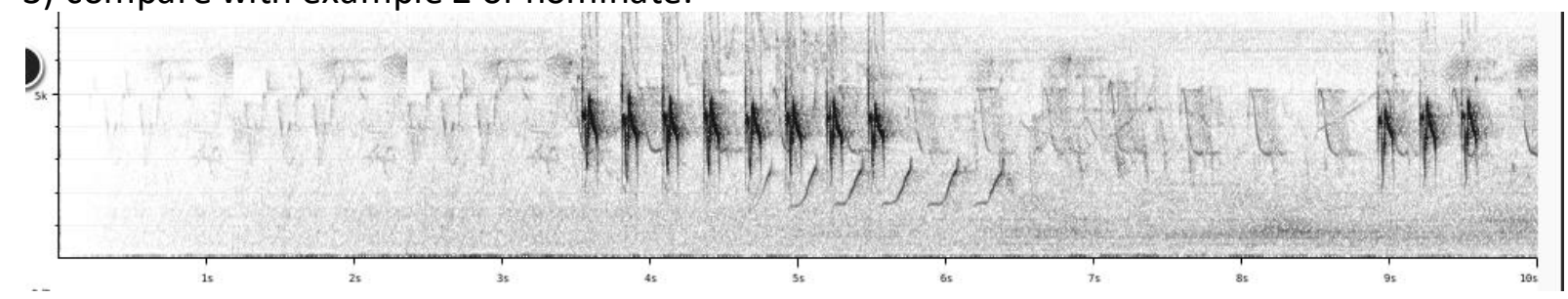

4) compare with example 3 of nominate and (to a lesser extent) example 5 of khasiana:

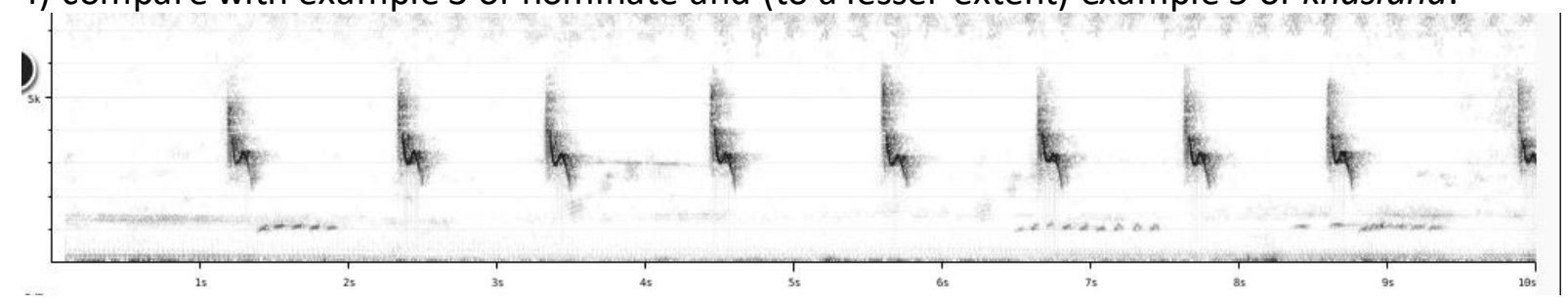




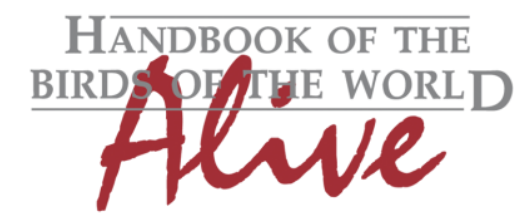

\section{ORNITHOLOGICAL NOTES}

and other variants:

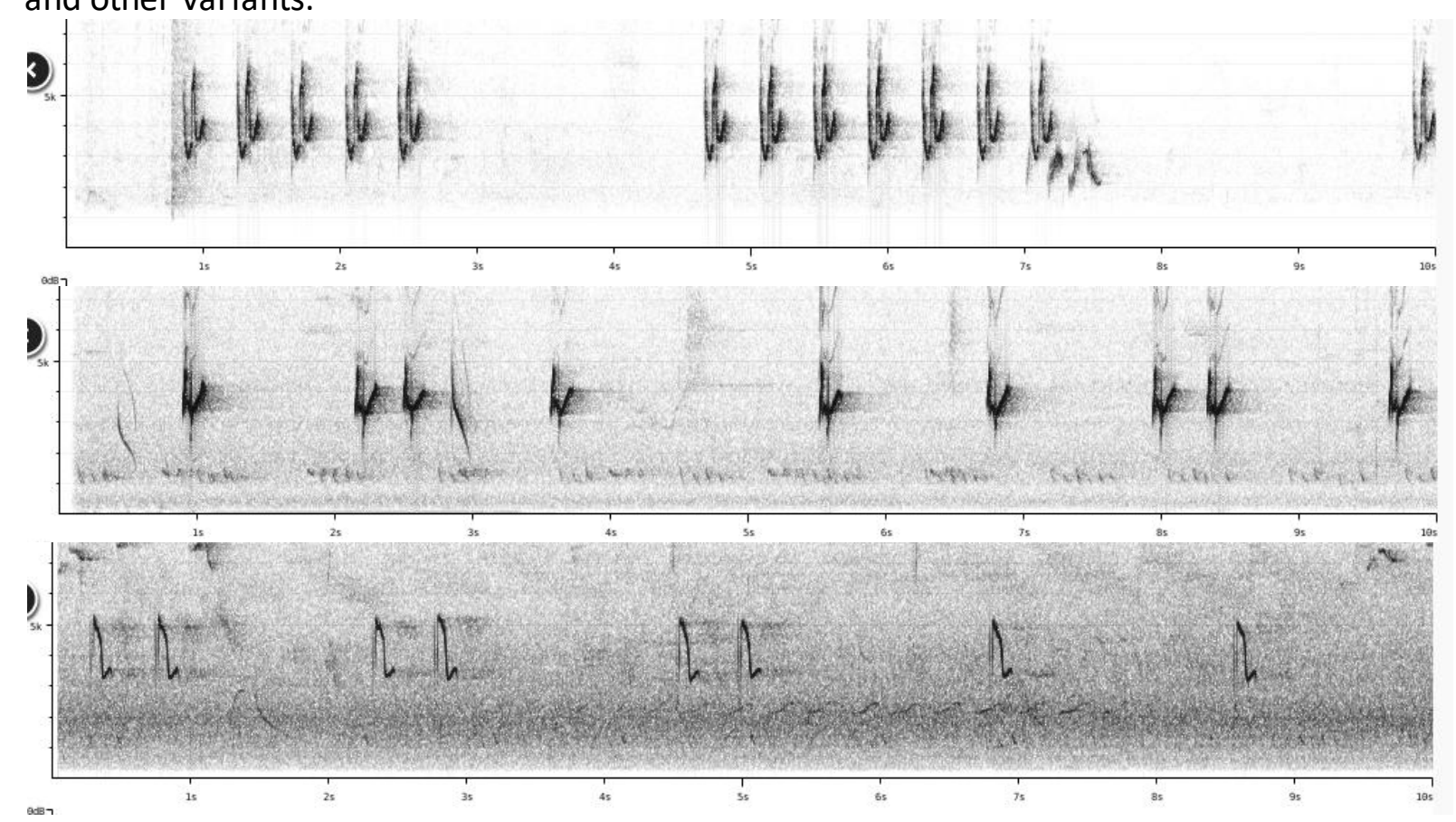

It would seem that with increasing availability of recordings, there is also an increasing overlap in vocabulary. The vocal difference between nominate/khasiana and other races is seemingly much less pronounced than indicated by Rasmussen et al. (2012).

There may obviously be slight differences in vocabulary, but from the above it would seem that khasiana differs vocally as much from nominate (or more) as from other races.

A more in depth study would be needed to identify truly unique characters of nominate and/or khasiana.

This note was finalized on 10th February 2016, using sound recordings available on-line at that moment. We would like to thank in particular the sound recordists who placed their recordings for this species on $\mathrm{XC}$ :

\section{References}

Rasmussen, P.C. \& Anderton, J.C. (2012). Birds of South Asia: the Ripley Guide. Lynx Edicions, Barcelona.

Tobias, J.A., Seddon, N., Spottiswoode, C.N., Pilgrim, J.D., Fishpool, L.D.C. \& Collar, N.J. (2010). Quantitative criteria for species delimitation. Ibis 152(4): 724-746.

\section{Recommended citation}

Boesman, P. (2016). Notes on the vocalizations of Hill Prinia (Prinia atrogularis). HBW Alive Ornithological Note 227. In: Handbook of the Birds of the World Alive. Lynx Edicions, Barcelona. (retrieved from http://www.hbw.com/node/932188 on 28 September 2016). 